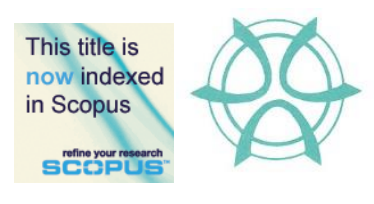

PLANNING MALAYSIA:

Journal of the Malaysian Institute of Planners

VOLUME 15 ISSUE 2 (2017), Page 37 - 50

\title{
SOCIAL IMPACT OF FOREIGN IMMIGRANTS IN AFFORDABLE HOUSING AREA. CASE STUDY: MENTARI COURT, SELANGOR, MALAYSIA
}

\author{
Oliver Ling Hoon Leh ${ }^{1}$, Nik Nurul Farahanis Mohd Rosli ${ }^{2}$, Farah Ayuni \\ Marhalim $^{3}$, \& Siti Nur Afiqah Mohamed Musthafa ${ }^{4}$ \\ ${ }^{1,2,3,4}$ Faculty of Architecture, Planning and Surveying, \\ UNIVERSITI TEKNOLOGI MARA (UiTM)
}

\begin{abstract}
Social impact can be defined as the net effect of an activity on a community and the well-being of individuals and families in the community. Among the activities that give rise to social impacts is the influx of foreign immigrants into a locality. This study examines the impacts of foreign immigrants' presence on the local society at an affordable housing area in Selangor. A questionnaire survey was carried out among respondents that were selected from the local residents to examine impacts on family relationship, the relationship among local residents, the relationship between locals and foreigner, acceptance of foreigners by local residents, sense of belonging, housing price, job opportunity, and safety. Overall, the results show that most of the respondents felt that the presence of foreign immigrants in the study area has negatively affecting them with regard to family and community relationship, sense of belonging, safety and housing price/rental.
\end{abstract}

Keywords: Community, housing, immigrant, impact, social aspect

Date Received: $26^{\text {th }}$ July 2016

Date of Acceptance: $6^{\text {th }}$ July 2017 
Oliver Ling Hoon Leh, Nik Nurul Farahanis, Farah Ayuni, \& Siti Nur Afiqah

Social Impact of Foreign Immigrants in Affordable Housing Area. Case Study: Mentari Court, Selangor, Malaysia

\section{INTRODUCTION}

Malaysian urban areas, especially Klang Valley, are facing challenges of limited housing supply that is affordable for the general public. The situation has become more complicated with the concentration of foreign immigrants in the affordable housing area, particularly low cost and medium cost apartments. The presence of foreign immigrants might discourage locals to stay in the affordable housing areas, thus, further decreases the availability of affordable housing for local residents.

According to Azhar (2012), one of the black areas in Petaling Jaya with high immigrant related crime rate was Mentari Court Apartment. Cases of crime and social problems were frequently reported. The crime cases associated with foreign immigrant include rape, sexual harassment, robbery, burglary, quarrel with local people, vandalism and so on (Azhar, 2012). This was made worse due to the aggressive behaviour of the foreign immigrants who like to make noise, fight among themselves, and being drunk and rude towards the local people. As a result, local residents seemed to be uncomfortable to share facilities at the apartments with them. Besides the study area, the presence of foreign immigrants has also created problems in other areas such as in Damansara Damai and in Taman Perumahan Rakyat Lima Kedai (Idris, 2013; Majid, 2014).

Due to the problems associated with foreign immigrants at residential areas, especially in the Klang Valley, this study was conducted with the aim of identifying the social impacts of their presence on the local residents in the Mentari Court Apartment in Petaling Jaya, Selangor.

\section{LITERATURE REVIEW}

Social impact can be defined as the net effect of an activity on a community and the well-being of individuals and families (The Centre for Social Impact, 2015). Social impact is related to the changes in value systems, individual behaviour, family structure, relationship, collective lifestyles, safety levels, moral conduct, creative expressions, traditional ceremonies, community organizations, economic benefits, opportunities, employment, education, health, social wellbeing, life chances, exposure to violence, trauma symptoms, community problems, and others including environment (McCombes, Vanclay \& Evers, 2015; Butcher et al., 2015; Nzeadibe et al., 2015; Social Investment Scotland, 2015). These aspects of social life are important because they affect the level of happiness of the people (Ling, et al., 2015).

Social impacts are always measured based on the people perception using participatory methods (Butcher et al., 2015; Nzeadibe et al., 2015). Impacts are measured based on social values and perception of the people. Previous studies have reported various impacts of foreign immigrants on the local community, especially in developed countries. For instance, results from Sweden, Denmark, and the USA showed that most immigrants reside in cities, where they are 
PLANNING MALAYSIA

Journal of the Malaysia Institute of Planners (2017)

overrepresented compared to the local population (Hedberg \& Tammaru, 2010). Within the cohort of immigrants arriving in Sweden in 1997-2002, 46 percent resided in large city-regions, compared to one-third of the Swedish-born population (Hedberg \& Tammaru, 2010), resulting in impacts on the labour market in Sweden.

In the USA, there was widespread belief that immigration is harmful to the economic welfare of the country, especially to native-born Americans (Hirschman, 2014). One the reasons was because immigrants are willing to work for lower wages. For some, immigrants are also thought to be an economic burden because they disproportionately receive public benefits, such as healthcare, schooling and welfare without paying their fair share of taxes. However, these claims were not supported by empirical evidence (Hirschman, 2014).

Based on the report of the National Research Council (NRC), immigration does expand labour supply and may increase competition for jobs and lower wages for native workers who are substitutes for immigrants, but immigration also expands total production (national income) and increases the incomes that accrue to native-born workers who are complements to immigrants (Hirschman, 2014). The arrival of unskilled immigrant labour may 'push up', rather than 'push out', many native-born workers (Hirschman, 2014).

A study by Hipp and Boessen (2012) over a nearly 50-year period in Southern California shows minimal evidence that immigrant influx had negative consequences for a neighbourhood. Contrary to popular belief, there is little evidence that an increase in immigrants decreases home value and unemployment rates. There is some evidence that neighbourhoods with more immigrants experience more vacancies over time, which may reflect preferences in response to such inflow (Hipp \& Boessen, 2012).

Besides, Europe has become home to millions of 'foreigners' (Semyonov, Raijman \& Gorodzeisky, 2008). The emergence of new ethnic communities in the host countries has not only changed the ethnic composition of European societies but also has led to increased ethnic tension between minority and majority members (Semyonov, Raijman \& Gorodzeisky, 2008). Many citizens have begun to view the 'foreigners' as a serious social problem, including a competitive threat. The impacts include job creation/scarcity, health and welfare systems, cultural life, crime (safety), and economy (Semyonov, Raijman \& Gorodzeisky, 2008).

In Singapore, government leaders on various occasions have expressed concern about the potential social impact of a large pool of migrant, particularly unskilled workers and overdependence on foreign labour (APMRN, 1997). Among the problems raised was the potential competition for the use of resources such as public space, transportation, and so on. In general, the problems related to foreign worker (immigrants) include overcrowding on roads and other public spaces, littering, vandalism, urinating in public and theft. However, no instances 
Oliver Ling Hoon Leh, Nik Nurul Farahanis, Farah Ayuni, \& Siti Nur Afiqah

Social Impact of Foreign Immigrants in Affordable Housing Area. Case Study: Mentari Court, Selangor, Malaysia

of violence or open conflict involving locals and foreign workers have surfaced (APMRN, 1997).

\section{RESEARCH METHODOLOGY}

\section{Scope of Study}

This study focused on the social impacts of foreign immigrants in the Mentari Court Apartment, Petaling Jaya, Selangor. For the purpose of this study, the scope of social impact was limited to the following aspects:

a) Safety;

b) Family relationship;

c) Community relationship among local residents;

d) Relationship between local residents and foreign immigrants in their residential area;

e) Sense of belonging among local residents;

f) Housing price due to the presence of foreign immigrant; and

g) Job opportunity.

\section{Case Study}

Mentari Court Apartment is located within the administration boundary of Petaling Jaya City Council. It is one of the main residential development in the Sunway City township. It consists of seven blocks with a total of 1,428 unit of apartments. The main surrounding land uses are industry and commerce. There are also residential areas located adjacent to the Mentari Court (Figure 1 and Photo 1).

The study area is well connected with roads and public transportation networks. The study area is directly connected to the Federal Highway, Damansara Puchong Expressway (LDP) and Shah Alam Expressway (KESAS). In terms of public transport connection, Setia Jaya Commuter Station (SentulPort Klang KTM Commuter Route) is located beside the study area. It is an integrated station that also caters the new Bus Rapid Transit (BRT) route.

The majority of the residents in Sunway City are locals. However, after Mentari Court was constructed, there was an increase in the number of foreigners in the area. This was because many of the companies in the area have rented the apartments and used the units as accommodation for their workers. Despite Mentari Court was developed as affordable housing for the locals, it attracted immigrants to stay in the area mainly because their companies pay the rent and the location is close to their workplace. For instance, most of the foreign immigrants, especially ladies, work at Western Digital factory which is located within walking distance from the study area. Based on the observation by apartment's management body, around 50 percent of the units in the study area are occupied by foreign immigrants (workers). 
PLANNING MALAYSIA

Journal of the Malaysia Institute of Planners (2017)

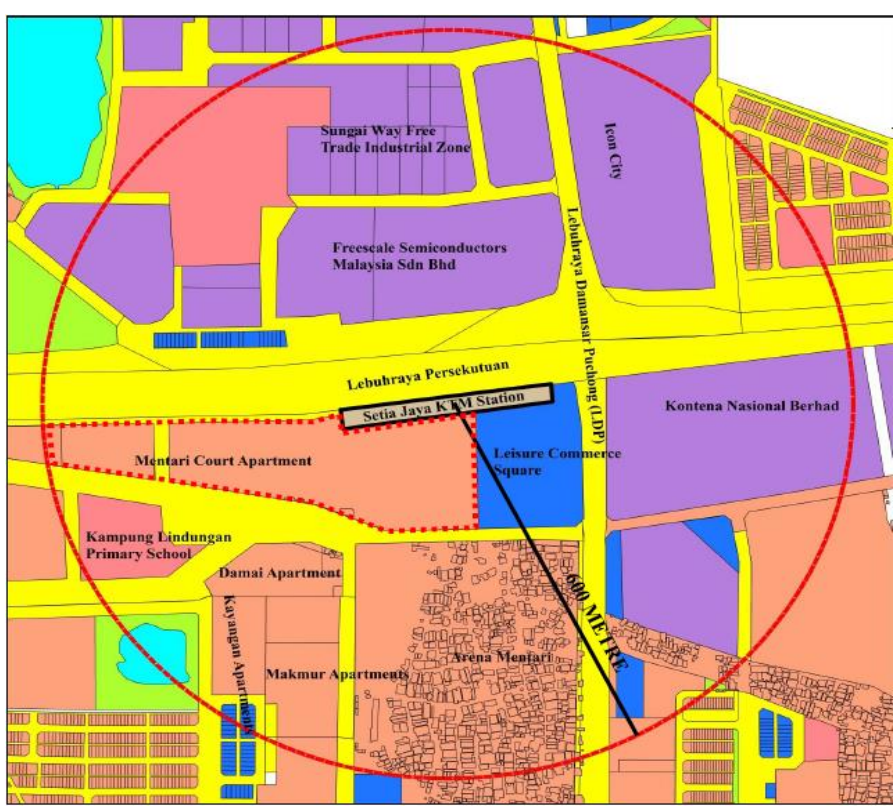

Figure 1 Mentari Court Apartments and surrounding land uses

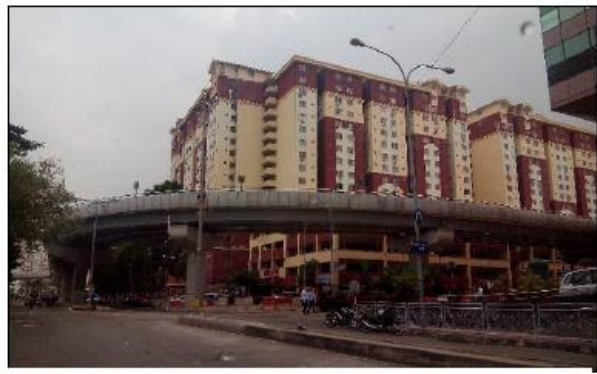

Photo 1 View of Mentari Court Apartments

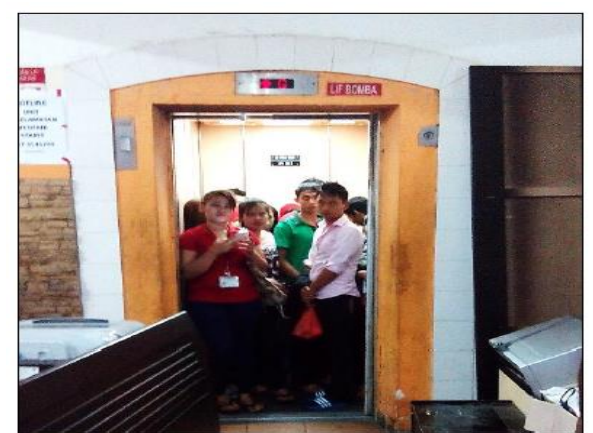

Photo 2 Sharing of facilities among local and foreign residents 
Oliver Ling Hoon Leh, Nik Nurul Farahanis, Farah Ayuni, \& Siti Nur Afiqah

Social Impact of Foreign Immigrants in Affordable Housing Area. Case Study: Mentari Court, Selangor, Malaysia

\section{Questionnaire Survey and Sampling of Respondents}

Data was gathered through face to face questionnaire survey among local residents in the study area. A total of 144 respondents were selected from the total population of 6,426 in the study area by using simple random sampling method. The samples were identified with a confidence level of $95 \%$. The samples included male and female, three (3) major ethnic groups in the study area, and different age groups (Table 1). The major questions in the questionnaire covered the following aspects:

a) Overall impact of foreign immigrants on themselves, family and study area;

b) Impact on family relationship;

c) Impact on relationship among local residents;

d) Community relationship between locals and foreigner;

e) Acceptance of foreigners by local residents;

f) Impact on sense of belonging;

g) Impact on housing price;

h) Impact on job opportunity; and

i) Impact on safety of the area.

Table 1 Background of Respondents

\begin{tabular}{lc}
\hline Variables & Percentage (\%) \\
\hline Gender & \\
\hline Male & 39 \\
Female & 61 \\
\hline Ethnicity & 28 \\
\hline Malay & 26 \\
Chinese & 24 \\
Indian & 22 \\
Others & \\
\hline Age & 13 \\
\hline$<21$ years old & 31 \\
21-40 years old & 42 \\
41-65 years old & 14 \\
\hline 65 years old & \\
\hline
\end{tabular}

\section{Method of Analysis}

Data was analysed using the built-in frequency, cross-tabulation and Chi-square tests of the Statistical Package for Social Science (SPSS) software. The purpose of the analysis is to find out the impacts of the existence of foreign immigrants on the different groups of local residents. 
PLANNING MALAYSIA

Journal of the Malaysia Institute of Planners (2017)

\section{RESULTS AND FINDINGS}

Overall Impact on Themselves and Family

Based on the questionnaire survey, around $72 \%$ of respondents felt that the presence of foreign immigrants has a negative impact on them, their family and the housing area in general (Table 2). The foreigners were associated with unhealthy and unethical acts such as fighting, being drunk, involved in black money scam and money laundering, and drugs abuse and pushing.

Table 2 Overall Impact on Local Residents

\begin{tabular}{lcc}
\hline Impact & Number of respondents & Percentage (\%) \\
\hline Positive & 14 & 9.72 \\
Negative & 103 & 71.52 \\
No answer & 27 & 18.75 \\
\hline Total & 144 & 100.00 \\
\hline
\end{tabular}

Table 3 Overall Impact on Local Residents by Gender

\begin{tabular}{lcccc}
\hline \multirow{2}{*}{ Gender } & \multicolumn{3}{c}{ Impact $(\%$ of respondents $)$} & \multirow{2}{*}{ Total } \\
\cline { 2 - 4 } & Positive & Negative & None & \\
\hline Male & 8.92 & 57.15 & 33.92 & 100.00 \\
Female & 10.23 & 80.67 & 9.10 & 100.00 \\
\hline
\end{tabular}

Based on gender, it was found that more female respondents $(81 \%)$, as compared to male respondents (57\%), felt that the presence of foreign immigrants has negative impacts on them (Table 3). Women are more easily affected by the feeling of unsecured and threatened by the presence of foreign immigrants as compared to men. The association test between gender and impact revealed a chisquare value of 13.970 which was significant at the 0.01 level $(p=0.001)$, demonstrating a significant association between gender and perception on the impact of foreign immigrants.

Meanwhile, in terms of age groups, higher percentage of young respondents (40 years old and below) was negatively affected by the presence of foreign immigrants in their residential area as compared to other age groups of respondents (Table 4). However, the association test (chi-square) showed that there was no significant association between age groups and their perception on the impact (chi-square value $=8.144 ; \mathrm{p}=0.228$ ). 
Oliver Ling Hoon Leh, Nik Nurul Farahanis, Farah Ayuni, \& Siti Nur Afiqah

Social Impact of Foreign Immigrants in Affordable Housing Area. Case Study: Mentari Court, Selangor, Malaysia

Table 4 Overall Impact on Local Residents by Age Groups

\begin{tabular}{lcccc}
\hline Age group & \multicolumn{3}{c}{ Impact (\% of respondents) } & \multirow{2}{*}{ Total } \\
\cline { 2 - 4 } & Positive & Negative & None & \\
\hline$<21$ years old & 5.52 & 83.36 & 11.12 & 100.00 \\
21-40 years old & 6.66 & 80.00 & 13.34 & 100.00 \\
41-65 years old & 11.47 & 68.84 & 19.69 & 100.00 \\
$>$ 65 years old & 14.97 & 50.04 & 34.99 & 100.00 \\
\hline
\end{tabular}

Photo 2 shows that the local residents had to share facilities such as lifts with foreign immigrants that could bring fear and insecure feelings to the local residents. The foreign immigrants were large in number especially during peak hours (early morning and at night) in most of the places in the study area, such as the lobby, lifts, parking area, and the entrance of the apartment.

\section{Impact on Family Relationship}

In general, the results of the analyses showed that all the aspects examined under this study was negatively affected by the presence of foreign immigrants. Firstly, the analysis on impact on family relationship showed that almost $75 \%$ of respondents felt that the presence of foreign immigrants in their residential area has negatively impacted their family relationship (Table 5). Parents, in general, were not favoured to allow their daughters to have close relationship with foreigners especially the Africans. Despite this, there were cases where their family members (especially young ladies) were having close relationship with the foreigners. This resulted in insecure feeling among parents (especially among the single parent families), and it has negatively affected the family relationship between parents and children.

However, some $8 \%$ of the respondents perceived that the presence of foreign immigrants has given a positive impact on the family relationship. This group of respondents took this challenge by taking their responsibility towards family seriously by spending more time with their family members, taking care of them, and also improving the communication and relationship with them.

Table 5 Impact on Family Relationship

\begin{tabular}{lcc}
\hline Impact & Number of respondents & Percentage $(\%)$ \\
\hline Positive & 12 & 8.33 \\
Negative & 107 & 74.30 \\
No answer & 25 & 17.36 \\
\hline Total & 144 & 100.00 \\
\hline
\end{tabular}


PLANNING MALAYSIA

Journal of the Malaysia Institute of Planners (2017)

Table 6 Impact on Relationship among Local Residents

\begin{tabular}{lcc}
\hline Impact & Number of respondents & Percentage (\%) \\
\hline Positive & 29 & 20.14 \\
Negative & 111 & 77.08 \\
No answer & 4 & 2.78 \\
\hline Total & 144 & 100.00 \\
\hline
\end{tabular}

\section{Impact on Relationship among Local Residents}

$77 \%$ of the respondents felt that foreign immigrants has negatively affected community relationship among local residents (Table 6). Due to the presence of foreign immigrants, the study area is now more heterogeneous in terms of community structure. It made the residents chose to communicate less and socialise less with neighbours due to the negative perception of locals on immigrants.

However, 20\% of respondents said that the presence of foreign immigrants gave a positive impact to the relationship among local residents. This was because local residents have become more united by forming Rukun Tetangga or neighbourhood association, and neighbourhood watch in order to fight the problems posed by the foreign immigrants.

\section{Community Relationship between Locals and Foreigners}

In line with the negative perception of locals on foreign immigrants, the relationship between locals and foreign immigrants in the study area was poor (Table 7). Almost $85 \%$ of respondents felt that the relationship between locals and foreigners was poor. Additionally, $78 \%$ of the respondents could not accept the presence of foreign immigrants in the residential area (Table 8).

The poor relationship and the failure to accept foreign immigrants' presence are associated to the different culture and aggressive attitude of the immigrants. For instance, the African immigrants like to make noise by singing loudly and dancing in their free time especially at night. They are also involved in fights. Locals also feel uncomfortable sharing facilities, especially swimming pool, with them. Furthermore, locals also have negative perception on the African immigrants by associating them to crimes, such as being drug dealers, gangsters and so on. However, according to the respondents, some of the foreign immigrants, such as those from Saudi Arabia and Pakistan, who practised the Islamic ways and culture, were acceptable by the locals. 
Oliver Ling Hoon Leh, Nik Nurul Farahanis, Farah Ayuni, \& Siti Nur Afiqah

Social Impact of Foreign Immigrants in Affordable Housing Area. Case Study: Mentari Court, Selangor, Malaysia

Table 7 Impact on Relationship between Local Residents and Foreign Immigrants

\begin{tabular}{lcc}
\hline Impact & Number of respondents & Percentage (\%) \\
\hline Good & 9 & 6.25 \\
No good & 122 & 84.72 \\
No answer & 13 & 9.03 \\
\hline Total & 144 & 100.00 \\
\hline
\end{tabular}

Table 8 Acceptance of Foreign Immigrants by Locals

\begin{tabular}{lcc}
\hline Impact & Number of respondents & Percentage (\%) \\
\hline Acceptable & 31 & 21.52 \\
Unacceptable & 113 & 78.47 \\
\hline Total & 144 & 100.00 \\
\hline
\end{tabular}

\section{Impact on Sense of Belonging}

The majority of the respondents (84\%) said that the community was losing their sense of belonging in the area (Table 9). The locals do not feel they belong to the community of the area because half of the apartment units are occupied by foreigners making the area losing its Malaysian identity. Even those who have lived long in the study area (i.e. more than 5 years), they still did not feel that they belong to the area (Table 9). In fact, sense of belonging was the only social aspect examined under this study that none of the respondents felt that the presence of foreign immigrants has any positive impact on.

\section{Impact on House Price and Rental}

The majority of respondents (76\%) felt that the presence of foreigners in the study area has increased the housing price and rental (Table 10). However, 8\% of respondents felt otherwise. Based on observation, normally companies would pay higher rental for the purpose of using the apartment units as hostels for foreign workers. As a result, the presence of foreigners has increase the demand for housing units in the area and has, therefore, pushed up the rental and value of the apartment units.

Table 9 Impact on Sense of Belonging

\begin{tabular}{lcccc}
\hline \multirow{2}{*}{$\begin{array}{l}\text { Duration of stay in } \\
\text { study area }\end{array}$} & \multicolumn{3}{c}{ Impact (\% of respondents) } & Total \\
\cline { 2 - 4 } & Positive & Negative & None & \\
\hline$<1 / 2$ a year & - & 80.02 & 19.98 & 100.00 \\
$1 / 2-1$ year & - & 91.30 & 8.70 & 100.00 \\
$1-2$ years & - & 85.30 & 14.70 & 100.00 \\
$3-5$ years & - & 86.92 & 13.08 & 100.00 \\
$>$ 5 years & - & 73.07 & 26.93 & 100.00 \\
Overall & - & 84.02 & 15.98 & 100.00 \\
\hline
\end{tabular}


PLANNING MALAYSIA

Journal of the Malaysia Institute of Planners (2017)

Table 10 Impact on House Price and Rental

\begin{tabular}{lcc}
\hline \multicolumn{1}{c}{ Impact } & Nos. & $\%$ \\
\hline Price increase & 109 & 75.69 \\
Price decrease & 12 & 8.33 \\
No answer & 23 & 15.97 \\
\hline Total & 144 & 100.00 \\
\hline
\end{tabular}

Table 11 Impact on Job Opportunity

\begin{tabular}{lcc}
\hline \multicolumn{1}{c}{ Impact } & Number of respondents & Percentage (\%) \\
\hline Positive & 7 & 4.86 \\
Negative & 53 & 36.80 \\
No answer (not sure) & 84 & 58.33 \\
\hline Total & 144 & 100.00 \\
\hline
\end{tabular}

\section{Impact on Job Opportunity}

In terms of job opportunity, the majority of respondents (58\%) were not sure about the impact (Table 11). Only $37 \%$ of respondents felt that there was a negative impact on job opportunity as a result of foreign immigrants influx into the area. The majority of foreign immigrants in the study area work as labourers and factory workers, which are the low-paid segment not favourable by the locals. However, there are also small number of foreigners who operate grocery shops in the area.

\section{Impact on Safety of the Area}

None of the respondents felt that the presence of foreign immigrants has improved the safety level in the area (Table 12). However, majority of them felt foreign immigrants presence in the study area has significantly impacted safety level negatively in terms of burglary and the overall living environment due to noise and pollution made by the foreign immigrants, as well as due to lower sense of security among local residents.

Table 12 Safety Impact on Life, Property and Living Environment

\begin{tabular}{llcccc}
\hline \multirow{2}{*}{ Impact on Safety aspect } & \multicolumn{3}{c}{ Safety level (\% of respondents) } & \multirow{2}{*}{ Total } \\
\cline { 3 - 5 } & & Safe & Average & Unsafe & \\
\hline Life & On women & - & 77.08 & 22.92 & 100.00 \\
\multirow{3}{*}{ Property } & On children & - & 65.28 & 34.72 & 100.00 \\
& Burglary & - & 11.11 & 88.89 & 100.00 \\
\multirow{2}{*}{ Living } & Vandalism & - & 76.39 & 23.61 & 100.00 \\
environment & Quality/pollution & - & 31.94 & 68.06 & 100.00 \\
& Noise & - & 5.56 & 94.44 & 100.00 \\
& Sense of security & - & 35.42 & 64.58 & 100.00 \\
\hline
\end{tabular}


Oliver Ling Hoon Leh, Nik Nurul Farahanis, Farah Ayuni, \& Siti Nur Afiqah

Social Impact of Foreign Immigrants in Affordable Housing Area. Case Study: Mentari Court, Selangor, Malaysia

\section{CONCLUSION}

To conclude, the results of this study show that most of the respondents felt that the presence of foreign immigrants in the study area has negatively affecting them in terms of family and community relationship, sense of belonging, safety and house price/rental. The respondents also associated foreign immigrants with bad and aggressive behaviours as well as with crime. As a result, respondents could not accept a close relationship between their family members, especially their daughters, and foreign immigrants. Respondents also felt insecure and loss of sense of belonging due to the presence of foreign immigrants in large number in the study area. The negative perception of locals on the presence of immigrants has also been commonly reported in other countries, such as in the USA (Hirschman, 2014), Singapore (APMRN, 1997) and countries in Europe (Semyonov, Raijman \& Gorodzeisky, 2008).

To mitigate the negative social impacts of foreign immigrants in the study area, it is proposed that hostels for foreign workers (labourers and factory workers) may not be suitable to be mixed with local residents in the same apartment block. Specific hostels for foreign workers will be more welcomed by local residents.

This study focuses only the social impacts of foreign immigrants in an affordable housing area (low and medium cost apartments) where the majority of the foreign immigrants work in lower segment of employment such as labourers and factory workers. Thus, to complement this study, it is suggested that future studies should be carried out to examine impacts of the high-income or highly educated foreign immigrants on the society in high-cost housing areas. 


\section{ACKNOWLEDGEMENT}

The authors would like to thank the Ministry of Higher Education Malaysia and Universiti Teknologi MARA (UiTM) for funding the study through the RACE grant (Project Code: 600-RMI/RACE 16/6/2 (16/2013)). The authors would also like to thank all the departments, organisations and individuals who has contributed to this study.

\section{REFERENCES}

Asia Pacific Migration Research Network [APMRN] (1997). Migration issues in the Asia Pacific: issues paper from Singapore. United Nations Educational, Scientific and Cultural Organisation.

Azhar, I. A. (2012). Cabar pihak berkuasa. Metro. Available at: http://www2.hmetro.com.my/articles/Cabarpihakberkuasa/Article/

Butcher, F., Galanek, J. D., Kretschmar, J. M., \& Flannery, D. J. (2015). The impact of neighborhood disorganisation on neighborhood exposure to violence, trauma symptoms, and social relationship among at-risk youth. Social Sciences \& Medicine, 146, 300-306.

Hedberg, C. \& Tammaru, T. (2010). Neigbourhood effects and city effects: immigrants' transition to employment in Swedish large city-regions. The Stockholm University Linnaeus Center for Integration Studies Working Paper 2010:6.

Hipp, J. R. \& Boessen, A. (2012). Consequences of immigration for Southern California neighbourhoods over fifty years. The American Academy of Political and Social Sciences, 641, 192-219.

Hirschman, C. (2014). Immigration to the United States: Recent trends and future prospects. Malaysian Journal of Economic Studies, 51(1), 69-85.

Idris, M. N. (2013). Cekup 11 warga asing. Sinar Harian. Available at: http://www.sinarharian.com.my/mobile/edisi/utara/ops-6p-cekup-11warga-asing-1.168058

Ling, O. H. L., Marhalim, F. A., Mohamed Musthafa, S. N. A., Abdullah. Y. A., \& Marzukhi. M. A. (2015). The relationship of human happiness and neighbourhood planning: case study Puchong Indah housing estate, Selangor, Malaysia. Planning Malaysia, 13, 51-64.

Majid, A. (2014). Warga asing banjiri Lima Kedai. Utusan Online. Available at: http://ww1.utusan.com.my/utusan/Johor/20140502/wj_01/

McCombes, L., Vanclay, F., \& Evers, Y. (2015). Putting social impact assessment to the test as a method for implementing responsible tourism practice. Environmental Impact Assessment Review, 55, 156-168.

Nzeadibe, T. C., Ajaero, C. K., Okonkwo, E. E., Okpoko, P. U., Akukwe, T. I., \& Njoku-Tony, R. F. (2015). Integrating community perceptions and cultural diversity in social impact assessment in Nigeria. Environmental Impact Assessment Review, 55, 74-83. 
Oliver Ling Hoon Leh, Nik Nurul Farahanis, Farah Ayuni, \& Siti Nur Afiqah

Social Impact of Foreign Immigrants in Affordable Housing Area. Case Study: Mentari Court, Selangor, Malaysia

Semyonov, M., Raijman, R., \& Gorodzeisky, A. (2008). Foreigners' impact on European societies: public views and perceptions in a cross-national comparative perspective. International Journal of Comparative Sociology, 49(1), 5-29.

Social Investment Scotland (2015). Social Impact Report 2015. Available at: $\mathrm{http}: / / \mathrm{www}$.socialinvestmentscotland.com/social-impact-report-2015

The Centre for Social Impact. (2015). Official web site. Available at: http://www.csi.edu.au/ 